\title{
The Influence of Anima in Edgar Allen Poe
}

\author{
LIU Jun-min \\ Harbin Institute of Technology, Harbin, China
}

\begin{abstract}
Through the analysis of Poe's works and his life, the influence of anima in Poe's soul is explored in this study according to Carl Jung's theory of archetype. Anima is one of the archetypes, which made both negative and positive influences in Poe's life and literary creation, leading him to be the master of poetry and short stories, but also consumed his life and caused his death in the prime. In the study about the influence of anima in Poe, Anima was proved acting as the feminine complement factors in Poe's unconscious, and made Poe more sensitive in literary creation. As Poe knew the man's world and also understood the woman's world, which is the accumulative influence of both negative and positive influences of Anima in Poe, his literary creativity was strong and he had the unique aesthetics.
\end{abstract}

Keywords: anima, negative influence, positive influence, accumulative influence

\section{Introduction}

Edgar Allan Poe was a great American poet, editor, and literary critic of the 19th century, and his remarkable achievements have a profound impact on the whole literary world. Poe was one of the earliest American short story writers. He is considered as the inventor of the detective-fiction genre and best known for his poetry and horror fictions. His works explore profoundly the human psychology and describe the most secret corners of the inner world. Poe's special aesthetic tendencies and unique aesthetics penetrate between the lines of his poetry and short stories. Poe paid special attention to aesthetics and created beauty in his works, such as the mysterious beauty, the macabre beauty, the mortal beauty, the musical beauty, the classical beauty, the melancholy beauty and so on. That is why Edgar Ellen Poe defined poetry as "the rhythmic creation of beauty" and his horror fictions are regarded as the horribly beautiful and attractive works of art in which horror and beauty are mixed marvelously with insanity and rationality coexisting.

Poe like all the men was influenced by the anima in his soul. Anima is the "soul-image", "the spirit of a man’s élan vital, his life force or vital energy” (Guerin, Labor, Morgan, Reesman, \& Willingham, 2004, p. 181), which is not in the sense of religion but soul. Anima is "the contra sexual part of a man's psyche, the image of the opposite sex that he carries in both this personal and his collective unconscious” (Guerin et al., 2004, p. 181). "Carl Jung defined anima as the expressions of the feminine nature in the male's consciousness realizing the basic and primal image function” (Vincent Brome, 1978, p. 204, as cited in CHANG, 1999, p. 105), so anima is the feminine nature of a male, the feminine complements of the male collective unconscious, and the collection of female images in the male mind. "In the male’s collective unconscious, this collection of female images is left

LIU Jun-min, M.A., School of Foreign Language, Harbin Institute of Technology. 
through heredity, and through this collection, man can experience the feminine nature” (CHANG, 1999, p. 104).

"Anima” is a primal model form, and its connotation signifies the fact that there is a little feminine nature or gene in a male, which is not presented and does not disappear, but exists in a male's body to realize the feminizing function. (CHANG, 1999, p. 104)

Anima influences a man's temperament and his sense of art.

As a great poetry and writer, Poe’s literary creating capacity and aesthetic capacity are influenced by the anima in his soul, but there is still no thesis or treatise probing into it. As to Poe's works, there are two mainstream critiques: One is about the aesthetic values and the other is about the psychological analysis. QI's "The Classic Reconstruction Under the Threshold of Cultural Poetics: Commentary on Zhu Zhenwu's New Book A Review of a Study on Edgar Allan Poe" (2011), is one of the voluminous researches about Poe's poetry and short stories abroad and domestic, but QI also points out that in the study of Poe's work there is a problem in seeking breakthroughs and innovations in the literary critical methods on the base of the premier scholars and researchers. QI's review also focuses on Poe's aesthetic implication, aesthetic creation, and aesthetic factors. WANG’s "Psychoanalytic Theory and Modern Literary Criticism” (1992, p. 145) relates that Poe’s depressed emotions are condensed, and then presented in his fictional characters through "empathy". In order to stuff up blank in the exploitation of Poe's anima, this paper will probe into the negative, positive, and accumulative influence of anima in Poe through the analysis of his works and the reliable experiences in his life, which is invisible but existing in the initiation process of a literary master.

\section{The Negative Influence of Anima in Poe}

The existence and formation of anima is influenced by the man's mother. "If the man's mother brings negative influences on him, anima presents as the negative moods, such as dysphoria, irascibility, and melancholia” (CHANG, 1999, p. 106). Poe's mother, Elizabeth Arnold, was a famous actress at that time, and she was a beautiful woman. His father David Poe was also an actor, but his acting career was not smooth. When Poe was two years old, his father David Poe disappeared because of his blighted aspiration and straitened living circumstance. Elizabeth was abandoned with two sons and a daughter. Because of the ponderous burden of stretching herself to provide for the family, Poe's mother was ill at the October of 1811, and died just tow month later. At this time Poe was only three years old. A three years old boy already has the perception ability and memory. His mother's youth, beauty, and responsibility left a nice image in his memory. However, his mother's sorrow and obsession of being abandoned, her worry and bitterness of the straitened life, her despair and suffering of the disease, and her yearning and love for her children and life also became the everlasting pain and sorrow in Poe's life. Poe started his life with the memory of his affectionate mother and yearning for the affection from family. The memory of his mother carved a deep imprint in Poe's anima, so Poe sought the consolation in his writing career.

Poe's anima was shaped by his mother, and there was the death of beauty, the fear of being abandoned, the suffering of disease, and the desire for life in his anima inherited from his mother. These themes are presented in his poetry and short stories. The early death of Annabel Lee reflects the death of beauty. In the short story "The Black Cat” (1843), the young wife has just married for three years, but she was murdered by his drunken husband and her body was walled in the cellar by him, which reflects Poe's accusation of his mother's being abandoned and death of illness and sorrow. In the "The Fall of the House of Usher" (1839), the beautiful but sick Madeline 
with a "suspiciously lingering smile upon the lip" is encoffined alive by her brother, but she breaks the coffin and gets out at last, which reflects the suffering of illness and the desire for life. Most of the affection and love in family for Poe was from his foster mother, but she died at about 40 when Poe was 20 years old. The death of his foster mother deepened the shadow of death of beauty and losing of love in his anima.

The dark and depressed part of anima was not only reflected in his works, but also threatened his real life. The death of his mother and foster mother meant the being abandoning of Poe and the losing of the precious love. In the soul of Poe, the negative "mother-anima" seems to repeat "I am a nihil and meaningless entity" again and again (CHANG, 1999, p. 106). The suspicion of the meaning of life forced him to explore the secret corners of the inner world and became a master of psychological fictions. That is why Poe was honored as "the adventurer who dared to break into the horrible hell of human soul” by D. H. Lawrence (ZHU, 2010, p. 109). This negative theme derives a man's motion and feeling, and causes the fear of emergency, disease, and death. Poe's whole life was enshrouded in the pathetic, blue, and depressed mood shadowed by the negative anima in his soul, which to some degree prevailed on him to commit suicide. Poe died at the age of 40 by indulging himself drinking, taking drugs, being lost in the physically and mentally tiredness, and lacking in consolation. The anima is the feminine soul of a man. The death of beauties in Poe's works, such as the death of Annabel Lee, Berenice, Ligeia, and Madeline, reflects his soul suicide. He suffered from the bouts of depression and madness. In his letter to his mother-in-law, Poe wrote "I have no desire to live since I have done 'Eureka'. I could accomplish nothing more” (Harris, 2000, p. 1, as cited in Poe, 1948, p. 452), and then he attempted suicide by swallowing opium in 1848. At this time, anima became the fatal daimon for Poe.

\section{The Positive Influence of Anima in Poe}

The anima in Poe's soul was the feminine nature in him, so the stronger anima became, the more profound he understood woman, which helped him know clearly what kind of woman he really love. According to the theory of Carl Jung, "If a man can understand his anima, he will choose his love with its criteria, so he may enjoy a happy marriage with a great possibility" (CHANG, 1999, p. 106). The positive influence anima for Poe was on his only marriage which was happy, even though it was short-lived. No matter happy or sad, Poe's marriage life gave him inspiration of several profound and influential works. At the age of 27, Poe married his cousin Virginia who had even not reached the age of 14 . The marriage life was happy and warm. Unfortunately, in the January of 1842, Virginia expectorated blood because of tuberculosis, which aroused the memory of his mother expectorating blood in Poe's deep inner world. Anima was enhanced once more, so Poe became more sensitive literarily and he created "The Masque of the Red Death" at the same year. Five years later, Virginia died of illness, which was a fatal shock to Poe. At this year, Poe created "Ulalume—A Ballad" (1847) that memorialized the faithful love between them and "Eureka" about his view of life and universe. Three years later, Poe created “Annabel Lee” (1850) which was praised profusely. Poe’s anima became more active than before and the art in his works came to the prime.

After the death of Virginia, Poe lost his bosom friend, and he did not find the substituted one, so his anima was a kind of self-protection to fill his emotional vacancy. As the usual form of anima presents as the illusion of pornography, men will nourish their needs with the blue movies, strip, and reverie, which is the primal and natural feature of anima. Especially after the death of Virginia, Poe took drugs and drunk immoderately, because 
the women he fell in love with and had a relationship, such as Ester Anne Lewis, Mary Sue, Helen Whiteman, Mrs. Shelton and several women, were finally inaccessible. "As long as a man's attitude to the emotion of life is still childish, he will be uncontrolled and lost under this feature” (CHANG, 1999, p. 107). "From the moment of [Poe's] wife's death, he waged an unequal battle with a relentless fate” (Peeples, 1995, p. 330). Poe longed for consolation, but his failure of love enhanced his loneliness and sorrow. That is why Poe died at a young age because of drinking and taking drug. On the other hand, too much drinking leads to the losing of sexuality. The weaker his masculine nature in his soul was, the stronger his feminine nature in his soul was. The failure of love and drinking enhanced Poe's anima and his capacity of understanding women, but also depressed Poe, leading to his early death, and caused the great lost for the whole literary world.

"If a man is impotent to face some facts in his unconscious, anima will present and help him analyse his ego" (CHANG, 1999, p. 107). One of the important functions of anima is making a man's soul coordinating with sound internal values. In Poe's spiritual world, anima plays the role of a guide or an intermediary leading him to the internal world and unconscious ego. At the last years of Poe, the anima in his soul was enhanced to the prime, so his literary creativity also came to prime. Poe created "The Bells" (1848), when he heard the sound of church bell. In this poem, Poe's description of the sound of the church bell was the best conclusion of his whole life-living the happy but transitory childhood, then experiencing the last half of life with sorrow and hardships, finally coming to the end of life with a hear full of scars. Two months before his death, Poe created "Annabel Lee” throughout ages for his wife Virginia dead at the age of 22. As the guide or intermediary, anima invisibly helped Poe sing the last song from his inner world.

\section{The Accumulative Influence of Anima in Poe}

In Poe's life, the influence of anima was the process of accumulation, and it was in synchronism with his initiation process, because anima was part of his soul and "the basic source of life within the human being" (Allen, 1947, p. 317). This accumulative process of gradation has three phases. "The first phase is about the pure instinct of the biological relationship, and its perfect symbol is Milton's Eve” (CHANG, 1999, p. 107). In the short story "Berenice” of Poe, the narrator is crazily attracted by Berenice's teeth, so he digs her body out of the coffin and pulls her teeth out. The narrator's love to Berenice becomes biological attachment to her teeth. Then the phase is about "the embodiment the romantic and esthetic horizon, which is still based on the sexual features", such as "The Helen of Troy" (CHANG, 1999, p. 107). In the homonymous poem "To Helen”, "Thy hyacinth hair, thy classic face" is the embodiment of Jane Stith Stanard's beauty which is also sexual attractiveness. "The last phase is that anima composes the divine and pure embodiment of wisdom, such as the nymph like the Mona Lisa of DaVinci" (CHANG, 1999, p. 107). In the short story "Ligeia” (1838), the narrator describes Ligeia as a learned woman, as Ligeia is the embodiment of wisdom. Ligeia's resurgence in the body of Lady Rowena shows Poe's fear of death and love of life. The changes of the beauties in Poe's works record the accumulation of anima's influence.

The strong and active anima was an important factor in Poe's initiation to be a master in poetry and short stories. "When a man treats the emotion, mood, dream, and illusion transmitted by anima positively, he will convert them into some set forms, such as literature, panting, sculpture, music dance and so on" (CHANG, 1999, p. 107). Poe converted the themes including the death of beauty, the fear of being abandoned, the suffering of disease, the desire for life, the love of musical beauty, and the exploration of the secret parts of the inner world 
into the fictional characters in his poetry and short stories. "If this conversion process of a man is long-term and diligent, his individualization process will not only be an illusion, but also gradually become real and solid for this man” (CHANG, 1999, p. 107). “In Jung’s teaching, the process of individuation, or a recognition and integration of the unconscious contents of the psyche into consciousness, is the most important goal of human life" (Jurkevich, 1991, p. 47). Man who is influenced by anima will present a special gift in literature, panting, sculpture, music dance or other form of art, while Poe presented it in literary creation. As anima was the feminine complement factors in man's unconscious making Poe more sensitive, he knew the man's world and also understood the woman's world, so his literary creativity was strong and he had the unique aesthetics. Even though Poe died in his prime, as a master of poetry and short stories, he fully expressed his special literary gift in his works and left his unique aesthetics for the readers to explore.

\section{Conclusions}

The anima in Poe's soul was shadowed by the death of his mother, and then it was enhanced by the death of his foster mother. The dark and depressed part of anima was reflected in Poe's poems and short stories. The negative "mother-anima” threatens Poe’s real life. Poe's whole life was enshrouded in the pathetic, blue, and depressed mood shadowed by the negative anima in his soul, which to some degree prevailed on him to commit suicide. The anima in Poe's soul was the feminine nature in him, which helped him to understand women, so the heroines in his works were beautiful and attractive. His anima was enhanced once more by his wife Virginia's death and drinking. The strong anima also plays a positive role as a guide or an intermediary leading Poe to the internal world and unconscious ego, and invisibly helped Poe sing the last song from his inner world. The influence of anima was the process of accumulation during Poe's initiation process. The strong and active anima enhanced Poe's literary gift, so Poe realized his gift in his literary creation, and was honored as a master of poetry and short stories.

\section{References}

Allen, L. D. (1947, May). The literary background for Claudel’s parabole d'Animus et Anima. Modern Language Notes, 62(5), 316-320.

CHANG, R. S. (1999). The myth of human soul: Psychological analysis of Carl Jung. Wuhan: Hubei Education Publishing House. (常若松：《人类心灵的神话 : 荣格的心理分析》, 武汉 : 湖北教育出版社, 1999)

Guerin, W. L., Labor, E., Morgan, L., Reesman, J. C., \& Willingham, J. R. (2004). A handbook of critical approaches to literature. Beijing: Foreign Language Teaching and Research Press.

Harris, W. C. (2000, Spring/Summer). Edgar Allan Poe's Eureka and the poetics of constitution. American Literary History, $12(1 \& 2), 1-40$.

Jurkevich, G. (1991, Winter). Unamuno’s intrahistoria and Jung’s collective unconscious: Parallels, convergences, and common sources. Comparative Literature, 43(1), 3-59.

Peeples, S. (1995, Fall). Life writing/death writing: Biographical versions of Poe’s final hours. Biography, 18(4), 328-338.

QI, L. (2011). The classic reconstruction under the threshold of cultural poetics: Commentary on Zhu Zhenwu's new book A Review of a Study on Edgar Allan Poe. Contemporary Foreign Literature, 4, 164-168. (綦亮 : 《文化诗学视阈下的经典重构一评 朱振武新著<爱伦·坡研究>》，载《当代外国文学》2011年第4期，第164 168页。)

WANG, S. R. (1992). Psychoanalytic theory and modern literary criticism. Contemporary Foreign Literature, 144-152. (王守 仁：《精神分析理论与现代文艺批评》，载《当代外国文学》1992年，第144 152页。)

ZHU, Z. W. (2010). The tell-tale heart. Shanghai: Huangdong University of Technology. (朱振武 : 《泄密的心》, 上海 : 华东 理工大学出版社, 2010) 